\title{
Thomas Aquinas on Justice as a Global Virtue in Business
}

\author{
Claus Dierksmeier \\ Anthony Celano \\ Stonehill College
}

\begin{abstract}
The moral theory of Thomas Aquinas meets the present need for a business ethics that transcends the legal realm by linking the ideas of justice and virtue in an ingenious way. Thomas's virtue theory coordinates private and public activities through a set of context-invariant, justice-oriented norms with conceptual appeal to contemporary questions of global business ethics. In our article, we first sketch how Aquinas's theory can be also of relevance to a non-confessional audience through its appeal to the 'natural light of reason.' Then we explain how his theory of 'natural law' aligns his ideas of virtue and justice. From this vantage point, we address the tension between cultural diversity and moral uniformity in the economic sphere in general and in today's globalized business world in particular. Throughout the article, we aim to show how Aquinas's conception of virtuous business conduct gains inter-personal and inter-cultural validity that establishes social justice as the global virtue of business.
\end{abstract}

KEY WORDS: Aquinas, virtue, business ethics, corporate social responsibility, justice

\section{INTRODUCTION}

TN A GLOBALIZED WORLD, business ethics must cope with both the multicultural diversity of moral practices and a multiplicity of ethical theories that orient them, without surrendering to relativism. Our article explains how Thomas Aquinas artfully combines sensitivity to cultural differences with an ethics characterized by notional unity, conceptual clarity, and categorical acuity. In Thomas, justice functions as a global virtue that connects the economic sphere with the common good of humanity. As a relational virtue, justice expresses a communal orientation of the human being by intimately connecting the actions of individuals, firms, and society. Whereas many moral theorists have emphasized the communal benefit of virtuous and just actions, Thomas's theory also indicates how acting in accordance with moral principles promotes personal fulfillment. Since corporations are comprised of individuals, promoting virtuous and just actions leads to a higher realization of the human potentials of employees and thus to benefits for the respective companies. Unselfish behavior, oriented to the common good, lies hence in the self-interest of business (Arjoon 2000). 
We first sketch how Thomas's ethics can be of relevance also to a non-Christian audience through its appeal to the 'natural light of reason.' Then we explain how his theory of 'natural law' links his ideas of individual virtue and societal justice. From this vantage point, we show that societal justice necessarily entails an orientation towards social justice and how this normative orientation informs Thomas's economic ethics. Finally, we use the idea of social justice in order to distinguish between obligations to Corporate Social Responsibility and philanthropic acts of businesses, before drawing some general conclusions on Thomas's import on contemporary discussions, e.g., on the recent Encyclical "Caritas in Veritate." In all sections, we emphasize how Thomas manages the tension between cultural diversity and moral uniformity in the economic sphere, which gives his business ethics a lasting and increasingly wider importance in today's globalized business world.

\section{FROM REASON TO NATURAL LAW}

A modern reader may be surprised by the confidence that Thomas Aquinas displays throughout his works in the universal acceptability of counterfactual legitimacy standards ("natural law') for the legal and moral norms he proposes. How could he believe so firmly that his audience would share his assumptions about both the content and the validity of the strictures of ethical conceptions? Why did he not fear that the diversity of cultures and their respective ethical norms would doom to failure any and all attempts to construe a normative theory of global scope and appeal? In particular, how could Thomas assume that his version of a Christian ethics would be relevant also to people outside of his religious community?

What supports Thomas's confidence in the global legitimacy of his ethical doctrine is the philosophical conviction that through sound philosophical thinking the essential order of life is recognizable, at least in its most fundamental principles. Thomas holds that the "natural light" of reason (lumen naturale) ultimately leads to truth (S. th. I-II, 109, 1 ad 2; II-II, 8, 1 c; 15. 1; 171. 2 c \& 4 ob. 3; etc.). In his view, the human being is endowed with rational capacities sufficient for earthly life; they may be supervened, but are not contradicted or annihilated by 'supernatural' (lumen supernaturale), i.e., revelation-based, knowledge (S. th. I-II, 109, 1 ad 2). In emphasizing the capacity of human reason to reach truth unaided by faith, Thomas addresses the rational powers of every human being, everywhere and always (SCG $1,2)$. Studying the world in its own light, that is, uncovering the laws of nature as they show themselves to reason, honors God, he argues, because through creation we learn indirectly about its creator (SCG I, $7 \& 8$ and II, 4). True faith ought to be based upon worldly knowledge, since God chose to reveal himself also in, and through, his creation (De Ver. q. 14, 9, ad 8).

To be sure, not everything can be known through the conclusions of reason alone; in matters of faith and salvation the powers of rationality are inadequate (Sent. III, d. 1, q. 1, a. 2-3). Yet the basic tenets of theoretical philosophy can be known solely by reason, and the same holds for the fundamentals of moral reasoning $(S$. th. I-II 94, 2). According to Thomas, God's governance of the universe through "divine reason" (S. th. I-II, 91, 1) proceeds in ordering everything towards the good through 
eternal law (lex aeterna). Instilled into all things are "their respective inclinations to their proper acts and ends," so that by their natural law (lex naturalis) and their proper desires, all created beings are oriented towards their respective, proper good (S. th. I-II, 91, 2).

Thomas accepts the basic premises of Aristotle's teleological metaphysics and supplements them with a Christian interpretation of the intrinsic ends of human life, including the quest for the perfection of the soul (beatitudo). In the resulting scheme of created nature, human life receives an elevated status because the human intellect can comprehend the order that governs life by recognizing the natural laws of both human and sub-human life (De Ver. q. 21, a. 1). Unlike animals, however, human beings cannot rely solely on natural instincts to achieve their good $(S$. $t h$. I, 5, 1). As beings acting upon rational conceptions about the world, humans need to represent to themselves the goals (as objectives) they are to pursue; they need to make the implicit law that governs their lives explicit. For that reason, the natural law does not represent some naïve naturalism, but rather depends on a reason-based interpretation of human inclinations. It is a product of human freedom.

Humans need specific cultural forms in order to articulate ethical norms. While these forms may differ all around the globe, their core message has some invariant features that can be distinguished philosophically. In particular, moral insight advances through the unification of three different levels of ethical understanding: first, a principled insight that good is to be pursued and evil to be avoided (synderesis); second, a situational judgment (prudentia) that informs which kind of behavior meets the criteria of law, custom, and virtue that specify the good in each concrete context; third, knowledge (scientia) that identifies the specific factual nature of the case at hand. Whereas the second and the third form of moral reasoning are contingent upon the finite mental abilities and the limited scope of information available to the persons involved — and thus fallible — the first is not (Jordan 1994, Hoffmann 2011).

Taking a decisive step towards a global conception of ethics, Thomas teaches that all persons know in their heart of hearts that "good is to be done and pursued, and evil is to be avoided" (S. th. I-II, 94, 2); awareness of this fundamental principle (synderesis) can never be expunged; as an indestructible core of sustained righteousness (perpetuae rectitudinis) it resides forever in everyone (Sent. II, d. 24, q. 3, a. 3 ad 3; Lottin 1948, Stammkötter 2001, Celano 2007). No cultural and circumstantial conditions can overpower the awareness of the veracity and pertinence of this stricture. Notwithstanding this fundamental moral principle, people do not always agree on moral questions. What accounts then for their ethical disagreements?

Thomas explains: Whereas in theoretical philosophy our (descriptive) theories about the world may actually differ (because of flawed deductions, faulty premises, illegitimate inferences, etc.), potentially, i.e., under ideal conditions, all our judgments could converge. The world is but one, and to Thomas, diversity in its theoretical descriptions proves only that human knowledge of the world has not yet reached its ultimate, adequate, and all-integrative level (S. th. I-II 94, 2). Instead, in practical philosophy, that is, in regard to all moral (prescriptive) questions, the diversity of judgments is only sometimes an expression of non-ideal conditions. The variety of ethically charged customs and conventions also reflects the divergent 
contingencies of circumstance of moral practice (S. th. I-II 94, 4). Virtuous behavior can, and at times must, vary according to context (Barbieri 2001).

Obviously, this insight is of immediate relevance for the regional ethics of business and for its culture-specific application. In fact, any and all contemporary theories of business ethics must answer precisely this very question, where to delineate universal strictures from regional customs, lest they succumb either to obtuse universalism or obdurate relativism. When and how may circumstance change the ethical case in point, and how far does reason offer guidance even in changing environments? Are there global norms and virtues, and, if so, what are they? How can one assert anything as universal that goes beyond the narrow ethical minimum on which, empirically, there is a factual consensus between all cultures of the world (González 2003)?

In regard to these questions, Thomas departs from Aristotle. While 'the Philosopher' had described most moral virtues abstractly as the golden mean between irrational extremes, he held that there are few general principles to ascertain conceptually the concrete contours of the good. For Aristotle there can be no universal natural laws informing us about 'the' good. Comprehending and identifying the good in life is to him ultimately a matter of judgment, not knowledge. One best imitates wise men (phronimoi) who are accomplished in moral affairs, until such practice gradually shapes one's habits so that one becomes, eventually, capable of judging for oneself. Aristotle does not propose a relativist theory of action since he indicates that certain laws that conform to human reason are always just. He does not, however, place such laws beyond human origins, but rather bases them in turn upon the idea of the universal agreement of wise moral agents ( $N E \mathrm{~V}, 7,1134 \mathrm{~b} 17-30)$. Thus Aristotle attributes to human beings an "ability to internalize from a scattered range of particular cases a general evaluative attitude, which is not reducible to rules or precepts" (Burnyeat 1980: 80). The foundation for ethical rules lies, according to Aristotle, always in practice-and never in a superhuman set of eternal principles.

Thomas instead does acknowledge general precepts about virtue (S. th. II-II, 44, $2,1)$, and holds in fact that "all acts of virtue are prescribed by the natural law" ( $S$. th. I-II, 94, 3). Hence, if the essence of the latter is intelligible to human reason, so should be the nature of the former. Virtue pursues the good, while the natural law teaches what the basic goods of human life are. Whereas some (e.g., Nussbaum 1978) claim that with this argument Thomas turns the laudable flexibility of Aristotle's ethics into an overly rigid system, other interpreters (e.g., Crowe 1977, Hall 1992) emphasize that in Thomas's version, too, there is room for the adaptation of virtue to circumstance and context, without rendering the principle tenets of ethics relative. In the following, we will support this latter interpretation. In the idea of justice Thomas's ethics provides a global perspective without losing its sensitivity towards circumstantial specificity (Barbieri 2001; González 2003). While justice as a virtue is a characteristic of the individual, its 'natural' goals are directed toward a dimension of inter-personal validity and pertinence. 


\section{NATURAL LAW AND VIRTUE}

What exactly is Thomas's position on the question of unity and diversity in morals? What are those 'natural' goods that every man and every woman is bound to pursue? Observing the most fundamental human inclinations, Thomas lists the following as the basic goods of human life:

[I]n man there is first of all an inclination to good in accordance with the nature which he has in common with all substances: inasmuch as every substance seeks the preservation of its own existence, according to its nature. According to this inclination whatever is a means of preserving human life, and prevents its termination, belongs to the natural law. Secondly, there is in man an inclination to things that pertain to him more specially, according to that nature which he has in common with other animals: and in virtue of this inclination, those things are said to belong to the natural law, ... such as sexual intercourse, education of offspring and so forth. Thirdly, there is in man an inclination to good, according to the nature of reason, which is proper to him: as man has a natural inclination to know the truth about God, and to live in society: and in this respect, whatever pertains to this inclination belongs to the natural law; for instance, to shun ignorance, to avoid offending those among whom one has to live, and other such things regarding the above inclination. (S. th. I-II 94, 2)

The general principle 'to do good and to avoid evil' becomes thus much more specific when applied to these natural goods (preservation, procreation, education, etc.), that is, in the command to promote (and to abstain from hindering) their realization. Some concrete moral precepts can be inferred directly, e.g., a command, "such as 'one must not kill,' may be derived as a certain conclusion from the principle that "one should do harm to no one"' (S. th. I-II 95, 2), explains Thomas. Other norms, however, need further contextualization and reflection in order to afford us ethical guidance. For instance, while "the law of nature holds that the one who does wrong should be punished; that one is punished in such a manner is a [further] determination of the law of nature" (ibid.).

Thomas states that "synderesis is called the law of our intellect insofar as it is a habit containing the precepts of natural law, which are the first principles of human acts" (S. th. I-II, 94, 1 ad 2). The correlation of the dictates of natural law and the principles of synderesis unites the epistemic, the volitional, and the axiological aspects of moral universals so as to provide explicit direction in prudential decisions (Pinckaers 1995). Thomas constructs a hierarchy of duties within the natural law which specifies further the generic principle to pursue the good and to shun evil, and provides certain precepts (such as the maxim to prevent avoidable harm). Norms that can directly be concluded from said principles are likewise seen as valid across time and culture. No individuals, businesses, or governments are exempt from these strictures. This explication of the natural law in and of itself curtails the claims to validity from advocates of cultural specificity. For example, the enlisting of certain regional values in defense of violations of basic human rights would thus have to be rejected as illegitimate. No firm should ever abide by unjust laws, even though 
this may seem necessary to do business in certain places, as illustrated by the role of Microsoft and Google in China (Dann and Haddow 2008).

While requisite contextual differences in regards to the specificities of regional customs $(S$. th. I-II 95, 3) and temporal affairs (S. th. I-II 96, 1) are generally accepted by Thomas, ethical diversity also meets clear 'natural' limits. Not all variants introduced by circumstance and context are morally acceptable. Thomas points to the acceptance of thievery by some Germanic tribes, for instance, which, in his eyes, is not a legitimate cultural specification of the institute of property, but must rather be attributed to the depraved customs and corrupt habits of said Germans ( $S$. th. III, 94, 4-6). His reasoning is that such a custom cannot be accepted from a global vantage point, since it rests on a failure to connect a requisite derived precept ( $d o$ not steal) from the universal principle (do not harm). (S. th. I-II, 94, 6 ad 1) Similar judgments can certainly be made in regard to harsh labor practices in developing countries that violate the physical integrity of employees and make it impossible for the individual workers to flourish (Varacalli 1992).

For Thomas the fundamental imperative to advance the natural goods of human life helps in generating a substantial context-invariant body of moral norms, binding all humans, at all times and in all places, to life-conducive policies. The natural law provides a global ethical yardstick, according to which regional customs can be measured, both in the public and in the private sector (Williams 1993). Business actors just as much as governmental agencies or individuals, are called upon to meet standards whose global reach Thomas defends by stating that the virtuous conduct they demand derives from basic insights of human reason into the nature of the human good (S. th. I-II, 94, 3).

While a contemporary moralist might emphasize mostly the benefits of virtuous acts upon their recipients, Thomas also stresses the positive effects of justice upon its practitioner. Human virtue, he argues, not only renders the act good, but also improves the agent of the good deed. In fact, a natural inclination to act reasonably and virtuously is for Thomas common to all human beings ( $S$. th. I-II 91, 2), regardless of political, religious or geographical differences (S. th. I-II, 94, 4; 95, 2). Virtuous behavior unlocks otherwise dormant potentialities and helps individuals to make the most of themselves. People flourish from acting justly toward one another; it lies hence in the self-interest of individuals (and firms) not to be selfish (Arjoon 2000).

Since Thomas holds that "the natural law, in the abstract, can in no wise be blotted out from men's hearts" (S. th. I-II 94, 6), and due to this universal intelligibility of the fundamentals of natural law, no human being is ever wholly without an innate awareness of the good, and hence never thoroughly without any goodness at all. Even those, who commit atrocious sins, cannot thereby divest themselves of their rational nature as such, or of their potential to redirect their lives to the good $(S$. th. I-II 85, 2). While the moral worth of individuals, of course, changes with their actual actions and convictions, this fundamental capacity to moral reform highlights the dignity of each person as a human being, which remains untarnished by personal conduct (Zagzebski 2001). Each human being, therefore, is always - in business transactions just as in all other aspects of life-to be treated with respect for this very dignity (Melé 2009b). 
For the formulation of ethics in the age of globalization, this stricture, too, is of eminent importance, since it designates an unconditional respect for all human beings. Their essential status as subjects of dignity is not conditioned on worldly achievements; humans do not have to earn their right to a dignified treatment. Neither business nor society can legitimately reduce a human being to its economic function either on behalf of collective interests, or in response to individual misdemeanor. Human subjects should never be objectified into mere 'human resources' or sheer 'human capital' - that is the immensely practical and immensely important outcome of this philosophical-theological argument.

From these deliberations, two important conclusions can be drawn. First, a crosscultural insistence on the basic tenets of natural law cannot be dismissed as an illegitimate infringement on cultural sovereignty rights (Jacobsen and Bruun 2000); rather any practice that directly contravenes universal prescriptions can justly be proscribed (S. th. I-II, 95, 2). A clear stance in favor of the United Nations Declarations of Human Rights and its consistent application in the economic sphere is but the consequent translation of this ethics into our contemporary life world (Cahill 1980; Villa-Vicencio 1999). Since the command of the natural law addresses itself to all actors, i.e., to firms just as well as to individuals and states, the same holds for a corporate commitment to the realization of its ultimate principles, as expressed by the signatory companies to the United Nations Global Compact (Melé 2009b; Williams 2004).

Second, if an inclination to moral conduct is deemed essential for human life, anthropologies (such as the neoclassical homo oeconomicus-theorem) that overlook this normative dimension will necessarily err in their prognostic treatment of human behavior as well as in their recommendations for economic policy. Thus, with Thomas, one must reject as incorrect both the pseudo-scientific positivism and the concomitant ethical relativism that predominate modern economics (Steele 2004). In Thomas, a normative orientation is ascribed to the human being as such. Hence the prescriptive nature of human reason must inform any description of human agency; in brief, economics without ethics is - descriptively-as incomplete as it is flawed. Even more sharply one must reject the normative use of the homo oeconomicus-theorem, i.e., the-prescriptive-postulate that the sole purpose of economic activity is the (quantitative) maximization of utility. Instead, we need to argue for a much richer (qualitative) conception of economic success that includes notions of virtue and social responsibility (Cornwall and Naughton 2003). The beneficiaries from corporate success must be all stakeholders, not just shareholders (O'Brien 2009). While shareholder value may be a suitable control tool for corporate activity, from a Thomistic perspective it can never be the guiding principle of business (Koslowski 2000).

In order to substantiate these claims, one need not be a Christian. While Scripture contains transcendent concepts that do not appeal to everyone, in the essential questions of human conduct, Thomas holds that the moral precepts of Scripture and secular reason converge. The medieval jurist, Gratian, provides an example of one such convergence when he defends the proposition that everyone is bound to do for another that which one wishes to be done for oneself (Decretum, I, 1, prologue). 
While directly revealed through Scripture (Mt. 7:12), this rule is also just as evident to those who proceed through sound philosophizing to an understanding of human nature ( $S$. th. I-II, 94, 4 ad 1). Obedience to the Golden Rule is then, according to Thomas, something that can be demanded from anyone, anywhere and at any time, and can form the core of a world ethos (Küng 1990). While the application of this global call to virtue may be context-bound, its principle is not.

Since human reason can comprehend immediately and intuitively universal principles of morality and deduce from them various necessary and invariable conclusions, Thomas concludes that certain virtues (like theoretical wisdom) are practiced best in solitary contemplation ( $S$. th. II-II, 57, 1), and can, consequently, be developed even by the relatively young and inexperienced (Reichberg 2002). Yet for the sound development of social and political virtues, people need the companionship of others (Kenny 1999, Celano 1987). Thomas accepts, in other words, the Aristotelian division of virtues into intellectual and moral. The intellectual virtues (wisdom, understanding, science, art, and prudence) refer to a capability for excellence, but do not ensure acting from such abilities. One might have knowledge but not use it for good ends (Hoffman 2011), as exemplified in the technical intelligence that goes into 'creative accounting' or embezzlement. Clever tricksters use their cognitive abilities quite efficiently to align their actions in order to achieve immoral ends but, alas, not in order to correct them. What they lack is the governance of moral virtues over their voluntary choices (Westberg 1994) and the inclusion of the well-being of others in the pursuit of their own; it is the virtue of justice that assures said inclusion.

\section{NATURAL LAW AND JUSTICE}

Thomas says that "what is particular to justice among other virtues is that it orders a human being in those affairs which concern another" (S. th. II-II, 57, 1). Justice always requires an equitable treatment of the other (ibid.) according to a universally recognizable standard of fairness (S. th. II-II, 57, 1 ad 2). The idea of justice formulates a relational virtue that links an internal act of the moral agent's will to an external effect directed to another. This notion leads Thomas to define justice as a "habit according to which one gives to everyone what is right (ius) with a constant and perpetual will" (S. th. II-II, 58, 1). The designation of internal constancy of the will to justice implies that true justice not be limited to particular time and circumstances ( $S$. th. II-II, 58, 1, ad 3). Rather, the extension of the individual virtue of justice into social dimensions suggests a need for certain forms of institutional, e.g., legal, justice. Thomas demands a more general and more structural understanding of justice than one which only governs particular transactions between individuals.

Justice must manifest itself in public laws. These laws ought to represent more than the collective pursuit of individual self-interest; they should address the common good, not just aggregate interest (Frank 2007). Thomas extends the understanding of the essential nature of justice, which consists in arranging affairs in their correct order, beyond the commutative fairness of reciprocation. The virtue of justice is directed to others in common, and requires that one serving individuals within a community also serves that community at large. One must not pursue justice in a 
merely utilitarian fashion that purchases benefits for some at the cost to others. As a result, individual justice, when perfected, contributes to justice in society by aligning the forms and norms of legal justice with the general good ( $S$. th. II-II, 58, 5).

As a requisite extension of individual goodness to its societal object, the virtue of justice cannot, however, be limited to the legal realm alone. Instead, Thomas demands that all actions by individual and collective agents be characterized by the aforementioned spirit of fair and adequate treatment. Since, for Thomas, the human being is by nature inclined to social interactions, the main tenets of legal positivism and contractarian constructivism must be rejected: society can neither be understood nor maintained as a sheer legal artifact. A durable and healthy society requires that justice not only informs the rules of law; it also demands that justice inspire all norms of moral and social conduct, including the customs of business (Velasquez and Brady 1997). In promoting justice, an otherwise imbalanced equity of social proportion is restored, which legitimates the agent's position in society. Simply put, justice justifies, as it rectifies the agent's social relations, whether this agent be an individual or collective person such as a firm.

Justice commits one to form a sufficiently objective view of others and what is due to them ( $S$. th. II-II 58,1$)$; that is, through the orientation towards justice the otherwise overly individualistic notion of virtue gains a decidedly trans-personal content. By commanding alterity-oriented objectivity from the individual's world-view, justice calls for the virtue of prudence as well. The virtue of prudence connects the intellectual and the practical realm; it represents right reason in action(s). Prudence, itself an intellectual virtue, is needed for all moral virtues because it determines the proper means to desired ends and issues appropriate commands. In the moral realm, prudence determines the practical application of the naturally known ethical principles. Justice demands prudence, for example, because in obliging the individual to act with adequacy towards others, justice orders one to develop a keen understanding of the lives and needs of others. To act with justice to others demands the prudent integration of external standpoints and a sensitive regard for the specificities of others, i.e., bridging cultural and societal divides and overcoming ethical parochialism (Barbieri 2001). Applied to the business context, this approach directs the firm, for reasons of both justice and prudence, to a circumspect recognition of the concerns of all of its stakeholders (Argandoña 1998). Furthermore, by committing each and everyone to non-partisan perspectives and integrative viewpoints, the idea of justice promotes a more global worldview than a unilateral satisfaction of personal wants requires (Cima and Schubeck 2001).

While Thomas acknowledges and endorses the view that in different countries varying circumstances will lead to the construction of divergent social norms and legal codes (S. th. I-II 96, 5), he holds that certain strictures of natural law apply to all peoples around the globe (ius gentium) because of their shared humanity $(S$. th. I-II 95, 4). Thomas distinguishes those two types of law roughly as follows. Laws that are inexorable for social coordination and collaboration to function, also in regard to economic transactions (iustae emptiones, venditiones), Thomas designates as ius gentium, whereas norms to optimize communal life in moral terms (ad bonum commune civitatis) fall under the domain of ius civile (S. th. I-II 95, 4). As 
reflected in the later teachings of the School of Salamanca that largely developed its cosmopolitan business ethics based on commentaries on his works, through the ius gentium, the normative orientation of natural law extends to the socio-economic realm world-wide (Alves and Moreira 2010; Courcelles 2005; Melé 1999; Rivas 1999).

The diversity of global business practices notwithstanding, certain core elements of moral conduct can, and indeed must, be safeguarded universally. Although Thomas regards the specific ways and means of wealth allocation and management as alterable social constructs, his conception of ius gentium defends an all-integrative orientation of the business sphere, namely that the overall direction of economic activity must always be guided by justice towards the overarching end of natural law: the common good (S. th. I-II, 92, 1). In this substantive mandate, Thomas's understanding of natural law differs crucially from merely procedural conceptions of legal fairness, as espoused by the contractarian tradition. Whereas in the latter, justice is typically defined formally, as the result of mutual agreements under specified conditions, the former remains materially bound to human well-being. For example, while under the stipulations of the contractarian position wage-contracts can settle payments below the subsistence level, Thomas's natural law doctrine demands the payment of at least a living wage in order to satisfy the requirements of justice.

As Thomas's connection between law and justice, and especially the establishment of the precepts of justice as a duty to everyone (indifferenter omnibus debitum: ST II-II, q. 122 a. 6), can be understood as the beginnings of a concept of universal human rights (Finnis 2005: 23), the socio-economic dimensions of Thomas's concept of natural law (S. th. I-II, 91, 5) can today be well reformulated as common socio-economic rights of humanity that demand unconditional respect everywhere on the globe: Core mandates of socio-economic justice ought to attain world-wide legal sanction (Williams 1993).

\section{SOCIAL JUSTICE}

Beyond the traditional demands of commutative and distributive justice, Thomas proceeds to the idea (albeit not the term) of a social justice that binds as well as bonds individuals and societies. In what follows, we intend to show in several steps in which instances not only individual actors and governmental agencies, but also corporate agents, are bound to advance social justice, e.g., through engagements in Corporate Social Responsibility.

Thomas reiterates Aristotle's position that wealth is not an end in itself, but merely an instrument to attain higher goods ( $S$. th. II-II 118 ad 5). Thomas regards neither wealth as (always and necessarily) a good, nor poverty as (always and necessarily) an evil. Their assessment depends upon the role they play in human life (SCG III, 30,2 ). If riches make individuals anxious or immoral, then, he thinks, it is surely better that poverty frees them from these afflictions. One should, however, not go so far as to view poverty as a good in itself; it, too, is only of instrumental value and praiseworthy "only in so far as it liberates [one] from those things by which a human being is prevented from intending spiritual things.... And this is common 
to all external things that they are good to the extent that they lead to virtue, but not in themselves" (SCG III, 133, 4).

Although Thomas supports the idea that individuals hold possessions in keeping with their social position (suam conditionem, S. th. II-II 118, 1), he warns that whenever "the practice of virtue is hindered by them, they are not to be numbered among goods, but among evils" (SCG III, 133, 1). Thomas's repeated emphasis on the merely functional nature of possessions is of central importance for his socioeconomic philosophy overall. In contradistinction to modern (e.g., libertarian) notions Thomas defends concepts of property and profit that merely convey relative, yet never absolute, entitlements (Keys 2006). For Thomas's central socio-economic argument is that goods, whose value is contingent, neither express, nor fulfill human nature; in consequence, human beings do not have an unconditional human right to their possession. Material wealth is in agreement with the natural rights of human nature under the condition that it is regulated by human laws promoting both individual virtue and the common good. Wealth acquisition and profit-making are rendered legitimate through their wider social purposes alone.

Which are these social purposes of individual possessions? In the hierarchy of beings, the more self-guided and independent an entity is, the higher ontological rank it commands (SCG IV, 11, 1-5). A stewardship of human life over less developed forms of nature and thus human appropriations of mundane objects are justifiable in Thomas's view. Although the human being cannot own anything absolutely, since everything belongs in the last instance to $\operatorname{God}(S$. th. I-II, 66, 1), it is appropriate, argues Thomas, that the lower life forms serve the higher ones, which allows human beings to use and appropriate the natural wealth of the earth. Yet the use of the earth and its goods has been given to humanity in common $(S$. th. II-II, 66, 1). Legitimizing private ownership against a benchmark of initial equality, Thomas simultaneously limits the acceptable forms and manifestations of private properties through their social functions. For, prima facie, forms of property that exclude the use of others, i.e., 'private' property (from Latin: privare = to deprive, rob, strip away), do not fall within the domain of a common stewardship of the earth. Exclusive property rights are hence in need of moral justification, which can be found in the following arguments.

First because every man is more careful to procure what is for himself alone than that which is common to many or to all: since each one would shirk the labor and leave to another that which concerns the community, as happens where there is a great number of servants. Secondly, because human affairs are conducted in more orderly fashion if each man is charged with taking care of some particular thing himself, whereas there would be confusion if everyone had to look after any one thing indeterminately. Thirdly, because a more peaceful state is ensured to man if each one is contented with his own. Hence it is to be observed that quarrels arise more frequently where there is no division of the things possessed. (S. th. II-II 66, 2)

Far from giving unconditional support for the privatization of the earthly goods, this conditional justification qualifies and limits the individual right to exclusive property (Nixon 2007). Since private property is not a direct institution of natural law, but an 
institution justified indirectly by it ( $S$. th. II-II 57,3 ), Thomas states that, a fortiori, the specific "division of possessions is not according to the natural law, but rather arose from human agreement which pertains to positive law" (S. th. II-II, 66, 2 ad 1). Since the institution of private property has to be justified relative to its function in fulfilling natural law, specific property relations within a certain society can never be defended absolutely. They are always subject to critical scrutiny, whether they benefit or harm a given community.

Thomas argues one should "possess external things, not as one's own, but as common, so that one is ready to share them with others in their need" (S. th. II-II 66,2 ). While not demanding "that all things should be possessed in common and that nothing should be possessed as one's own," this passage does indeed mean that society can, and should, define proper boundaries of private possessions (ibid.). There is, in short, no abstract right to enrichment at the cost of the common good, either for individuals or for collectives, such as firms, since from a Thomistic perspective, all possessions are generally constrained by "the right of all persons to subsist upon the bounty of the earth" (Ryan 1942: 245).

The law accepts, however, the presence of many evils and the absence of numerous goods, on behalf of the higher good of human freedom which cannot otherwise be sustained (S. th. I-II, 96, 2). Hence the moral precept of almsgiving or philanthropy does not translate into laws of massive income redistribution. Yet at the same time Thomas also explicitly denies (the central tenet of libertarian doctrines) that legal provisions for the institution of private property can be used against the right of those in need. "Inferior things" — he declares as if addressing a neoliberal audience- "are ordered to assisting those in need. The obligation to assist those in need by such things is therefore not prevented by the division and appropriation of things which proceed from human law. And so things which some have in abundance should be used according to natural law to assist the poor" (S. th. II-II 66, 7). Human society, bound by the principle of justice for its legitimacy (S. th. I-II 95, 2), must never accept the superabundance of some in the face of the need of others (Schumacher 1949). Thus a strong case for redistributive action on all social levels is being made that can be extended to corporate actors as well (Kohls and Christensen 2002).

Although the exact term of 'social justice' has not been used by Thomas, it makes good sense to attribute this modern notion to his ethics. For, if we understand social justice as a regard for equitable forms of societal interaction with the objective of enabling each and all to lead a dignified life, then Thomas, without doubt, can be said to integrate said concern firmly into his conception of virtue. Social justice, so understood, is in fact central to his economic theory and business ethics, as it calls all actors and agents to contribute to the common good. In a Thomistic perspective, business cannot relegate all social responsibilities to the public realm. Instead, business is not only allowed but on occasion, such as given state failure or the total absence of public governance, required to act as a subsidiary facilitator of social justice (Aßländer 2011). 


\section{ECONOMIC ACTIVITY}

In its rejection of avarice and greed (S. th. I-II 84, 1), Thomas's socio-economic ethics builds upon Aristotle's distinction between oikonomia and chrematistike. While oikonomia represents the pursuit of certain material goods to supply a given household, chrematistike denotes (diverse forms of) wealth-seeking (Dierksmeier and Pirson 2009). Oikonomia is internally oriented towards determinate qualitative satisfaction levels (and thus quantitatively limited); chrematistike, however, operates on the merely quantitative logic of 'more over less.' A 'natural' and an 'unnatural' form of chrematistike must be distinguished. As long as chrematistic endeavors are still 'naturally' governed by the needs of oikonomia, they are, if only externally, also limited by the latter; unless other social goods are sacrificed in their pursuit, one can, if one must, legitimately engage in such chrematistic businesses. Altogether different is, however, the internally, as well as externally, unlimited pursuit of profit for profit's sake (Sison 2008). This boundless and, in the eyes of Aristotle, 'unnatural,' form of chrematistike meets with his stern disapproval: it upsets the just order of means (material, pecuniary) and ends (spiritual, contemplative), turns potentially the gain of one into the loss of another, and enhances typically the extant inequality in society to the detriment of both the poor (who are increasingly burdened) and the rich (who, absorbed in the pursuit of lesser goods, are ever more distracted from the true values of life).

Like many medieval authors Thomas joins Aristotle in his criticism of pleonexia. Yet he also provides a more neutral assessment of commercial exchange than Aristotle, who had accepted trade only as a necessary evil. For Thomas, exchange relationships, while often leading subjectively to a "certain debasement" of the involved tradesperson (S. th. II-II, 77, 4), are nonetheless viewed objectively as societal transactions without intrinsic faults: their moral value is, like that of private wealth, wholly functional. Whether commercial transactions are condemned or commended depends solely on what they accomplish for society. When they benefit all involved parties and achieve a better allocation of goods overall, they gain Thomas's approval (ibid.).

Merchants, for instance, are allowed to seek not only surplus returns for their labor, costs, and risks (i.e., as reimbursement for their transport and insurance outlays), but also moderate gains resulting from the fluctuations of general market prices and particular customer demand (ibid.). The reason behind this view is that for Thomas the "just price" that shall be observed in trade is not a quantitative fixture, but a regulative idea of a qualitative nature. It eliminates excessive pricing in order to prevent the exploitation of dependencies and need, without demanding static prices, fixed to an unalterable economic equilibrium ( $S$. th. II-II, 77, 1). For the later development of the feudal and mercantile economies into the capitalistic system, this slight deviation from Aristotle is of highest importance, and thus the quaestiones 77 and 78 in Thomas's Secunda secundae have produced vastly different interpretations (Alves and Moreira 2010).

Prima facie, Thomas seems simply to follow the many biblical injunctions against usury (Exod. 22:25, Levit. 25:37, Deut. 15:6, 23:19, Ps. 14:5, Lk. 6:34), and to 
reiterate Aristotle's charge against the 'sterile' nature of monetary transactions in favor of the 'fruitful' dimensions of commodity production and exchange. On second inspection, however, we see that Thomas's approach is more subtle. On one hand, Thomas does value labor over exchange and, in turn, commodity exchange over monetary investment when it comes to assessing the morality of revenue claims (Franks 2009). In short, the healthy preference of 'sweat equity' over capital returns that characterizes medieval philosophy in general also permeates Thomas's deliberations (Contra impugnantes, VI, ad 12). On the other hand, that does not mean Thomas would grant a legitimate role in generating income only to labor, and never to capital (Nell-Breuning 1983).

While Thomas censures money-lending as "usury" with many of the same arguments we find already in Aristotle and the Bible $(S$. th. II-II 78, 1) and while he also opposes the notion of interest as a legitimate reimbursement for opportunity costs (Recompensationem ... in hoc quod de pecunia non lucratur, S. th. II-II 78, 2 , ad 1), it would still be erroneous to conclude that Thomas simply espoused a labor cost theory and would have dismissed today's capitalistic economy therefore as illegitimate (cf. Orel 1930). Thomas does allow for gains without the input of labor, e.g., revenues from rent and also from investments (per modum societatis) in commercial enterprises (S. th. II-II 78, 2). Why these exceptions in favor of capitalbased income? The most convincing answer, in our judgment, proceeds from the postulation of social justice as the core virtue of business. In either of these forms, the invested money has served a socially productive function — e.g., building up real estate in the former, outfitting a merchant voyage in the latter-that is, the money has been used as productive capital, realizing social utilities that, without the expectation of profit, might have remained unrealized. This is where the crucial difference lies.

That money lending with interest was so staunchly rejected by Thomas must be seen before the backdrop of a medieval economy. At the time, private surplus funds were not yet identified as social capital, because they often remained idle or were used for ostentatious consumption (Epstein 2009). To lend money frequently demanded no more from the creditor than to reject the morally dubious pleasures of the wastrel or the miser. Those who asked for pay to forgo either option met consequently with moral indignation. An altogether different plane is entered, once we change the perspective and view money as capital (Nell-Breuning, Hengsbach, and Emunds 2002). Money can, after all, no longer function as a permanent measure of value when, as capital, it is itself traded. In a thoroughly capitalized and growing economy, money, too, carries a price, and so every outlay implies not only hypothetical opportunity costs but real expenses to the lender. While probably beyond the imagination of Thomas, it is not beyond the possibilities of his ethics to deal with such a state of affairs. With regard to the contemporary economy, Thomas might well have accepted income from capital investment, as long as-and this, sadly, is more often than not a counterfactual qualifier-it was gained in a way conducive to the welfare of all stakeholders of the respective transaction (Bailey 2010). What he would not, however, have endorsed is the current practice of externalizing the moral, social, and environmental responsibilities of business in the pursuit of higher financial gains. Since in his view these responsibilities are intrinsic to economic 
activity, they should be internalized into management, irrespective of whether or not sufficiently sanctioned laws demand the same. From a Thomistic perspective, therefore, the recent financial crisis appears as 'a perfect storm,' resulting from the combined effects of the deregulatory weakening of institutions of economic justice and waning socio-economic virtue.

In sum, Thomas does not necessarily tie income to labor, but rather to the social utility of the revenue-generating activity or entitlement. Therein lies an importantthen observed, today neglected - regulative ideal of all business transactions: profits are legitimate in a quantitative moderation that results from respecting the qualitative confines protecting the welfare of all stakeholders (Dierksmeier 2011). Mutatis mutandis, this thought may nowadays well serve as a guideline on the way towards a more humane and balanced economy (Cullen, Hoose, and Mannion 2007); namely Thomas's use of a counterfactual value theory, which limits the quantitative pursuit of profit by qualitative concerns for human well-being, and establishes a hierarchy of life-promoting goods that business is to procure, renders his theory most pertinent for our time. Defining the purpose of business in qualitative terms, it inspires us to include parameters such as virtue and social responsibility into our conceptions of good management (Knights and O'Leary 2006; O’Brien 2009).

\section{CORPORATE SOCIAL RESPONSIBILITY}

Thomas, obviously, wrote his ethics with a view to the business practices of his day. Insofar as the latter have changed, the specificities of former may have to be adapted to meet the altered realities of the present. Yet a transfer of his general ethical principles to our contemporary situation is still possible. For example, when commenting on the moral dilemma of a conscientious grain merchant, discussed already in Cicero (De off. III, 12, 50ff.) as a 'case study' on honorable conduct in business, Thomas clarifies his position on the legitimacy of business profits in a manner that proves instructive for present concerns and questions. In particular, Thomas uses this example to qualify where in economic affairs the dividing line lies between individual virtue and social justice. The basic question at hand was whether a grain merchant, who knew about an impending rise in supply and a subsequent decline in prices, should inform his customers thereof, or whether he could legitimately profit from their ignorance. Both views, the need for full disclosure and the acceptability of capitalizing on the information asymmetry, had been defended by ancient authors.

Thomas holds that while it "is always unlawful to give anyone an occasion of danger or loss," one is not always required to "give another the help or advice which would be of some advantage; but only in certain fixed cases, for instance when someone is subject to him, or when he is the only one who can assist him" (S. th. II-II, 77, 3). For Thomas, the salient point is thus whether actual harm is being done by the concealment of facts; for example, when a seller "offers a thing for sale [that] gives the buyer an occasion for loss or danger by offering him something defective" (ibid.). In that case, a business person would be under the legal responsibility to act on behalf of the welfare of his or her clients. In the instance of the grain merchant, however, "the goods are expected to be of less value at a future time, because of 
the arrival of other merchants, which was not foreseen by the buyers. And so the seller, since he sells his goods at the price actually offered to him, does not seem to act contrary to justice by not declaring what is going to happen" (ibid., ad 4.).

Whereas many of Thomas's intellectual predecessors operated from a singular concept of morality, extending across all types of human relationships and interactions, Thomas ascribes to the realm of business an ethical orientation of its own. While exempting the buyer from a legal obligation to reveal information whose concealment is not harmful but whose disclosure would render benefit to the customer, Thomas relegates this decision to business ethics proper. He declares it would be "exceedingly virtuous" (ibid.), i.e., praiseworthy, on part of the merchant, would he go beyond his legal obligations by informing his customers or through voluntarily lowering his prices. While this seems to indicate that Thomas operates with a dual scheme of moral versus legal responsibilities, he follows, in fact, a tripartite model of ethical obligations. Between the legal responsibility (to give what is due) and voluntary (supererogatory) ethical activity, lies a third realm, comprised of the social responsibility to a subsidiary contribution to social justice.

A glance at Thomas's theory of almsgiving clarifies this point. Thomas views almsgiving as not merely an ethical recommendation, but rather as a strict moral precept $(S$. th. II-II 32, 5), since it is "necessary to virtue, namely, in so far as it is demanded by right reason" (ibid.). Moral reason demands, Thomas explains, that any surplus we own beyond what we need for the maintenance of those in our charge, we are to give to the needy. Moreover, while "it is not possible for one individual to relieve the needs of all," we are bound to relieve all "those who could not be assisted if we not did assist them" (ibid.); and there is no reason why this precept for all "those who have riches" (SCG III, 135) should not hold as well for corporations (Kohls and Christensen 2002).

According to Thomas, we face three distinct classes of social obligations towards persons in need. First, legal strictures tell us to render to others what is their due or suffer pain of punishment. Second, a strict moral obligation demands that we, individuals as well as firms, give to others if a) they are in a position of dire need, b) we enjoy superabundance, and c) only we can help. We may, in such cases, still use judgment as to the mode of assistance (how to help), but not in regard to the nature of our duty (whether to help). Yet, if we fail altogether to assist the needy, we are blameworthy. Third, even in situations when we do not wield superabundant means, or when the need of the other is not extreme, or their destitution could still be mitigated by others, we are called to assistance; albeit then in a form that allows for the comprehensive use of our personal judgment (both as to whether and as to how we should help). If in those latter instances, we do not eventually support the person in need, we are not blameworthy. Instead, if we do, we are considered praiseworthy.

Thomas assigns only the third aspect to charity; the two anterior ones, however, are formulated from a perspective of justice. The virtue of justice thus not only extends in the individual realm to abstract, structural forms of institutional justice but also demands to advance social justice through concrete, material redistributions of assets (Kohls and Christensen 2002). Mapping these distinctions onto business, we can develop clear contours for a contemporary concept of corporate responsibility 
from the global virtue of justice (Kelly 2004). First, all corporations must abide by the law. Second, all firms have subsidiary duties to take on social responsibility, according to their respective capacities, whenever else the basic needs of their stakeholders remain unmet. Failure to meet this obligation is blameworthy. Third, philanthropic commitments beyond this second level remain voluntary, and are praiseworthy. They cannot, however, make up for insufficient compliance with the aforementioned legal and social responsibilities. Such supererogatory conduct does not replace action on behalf of a firm's legal and social responsibilities but rather complements it. Failure to deliver on the legal and social obligations of business entails, respectively, the sanctions of punishment and public blame, while no such sanctions await the individuals or the corporations abstaining from supererogatory activity.

An important consequence of this tripartite vision of the ethical obligations of a firm is that corporations cannot choose whether they want to be responsible corporate citizens or not. Firms can handle philanthropic activities according to discretion, but when it comes to their duties as a subsidiary agent of social justice, certain quantitative and qualitative strictures apply. Quantitatively one must hold that the more powerful firms are, the more they need to contribute to the common good. Qualitatively such contributions ought to consist in progressive industrial or sector-wide initiatives that aim at global governance improvements so as to turn the extant downward spirals of worldwide competition ("race to the bottom") into upward spirals of increasing protection for social and ecological standards (Santos and Laczniak 2009). Furthermore, in cases of state failure businesses act must act as subsidiary guarantors of justice and cater to the basic needs of their immediate stakeholders (Aßländer 2011).

In sum, according to Thomas, everyone (individuals, firms, businesses and governments) is obligated to the realization of social justice. This is why concrete social, not just abstract institutional justice must inform, as well as transform, every commercial transaction, here as anywhere else on the globe. In short, social justice is the global virtue of business. Such commitment to social justice centers the notion of corporate citizenship and gives it a clear mandate. Moreover, with Thomas's tripartite model of corporate responsibilities the interest of uniformity and diversity are both met. Cultural specificity encourages the use of context-specific judgment mostly in the ambit of the supererogatory realm of virtuous corporate behavior (whether and how to help), and it also allows for varying applications of the universal commitment of corporations to act as subsidiary agents of social responsibility (how to assist). Yet situational specificity cannot be adduced to ignore either the general social, or the particular legal, responsibilities of business. For both legal and social responsibilities are characterized by that universal and uniform global orientation of economic virtue that commits each business to the common good. Thus Thomas not only makes an important step towards a contemporary conception of business ethics as a dimension of responsible corporate conduct beyond what the law requires (Melé 2009a), but also helps us clarify the conceptual distinctions between a globally requisite form of Corporate Social Responsibility (e.g., in regard to the protection of human 
rights in supply chain management) and locally operative, judgment-based, forms of voluntary philanthropy (e.g., through corporate donations of time and money).

\section{CONTEMPORARY RESONANCE}

Thomas's economic ethics resonates strongly in the recent Encyclical "Caritas in Veritate." In this document, the sterile bifurcation between public and private realms, driven by allegedly entirely different logics, is criticized in favor of a perspective of economic life that integrates the private, the civic, and the public sector in view of the common good (Melé 2010). The Encyclical finds strong words against this "conviction that the economy must be autonomous, that it must be shielded from "influences' of a moral character" (CiV 34) which "has led man to abuse the economic process in a thoroughly destructive way" (ibid.). The "exclusively binary model of market-plus-State," we read, "is corrosive of society" (CiV 39). The neoliberal belief that for economic relations a logic of sheer commutative symmetry and quantitative equivalence would be sufficient, is rejected in favor of a demand "that in commercial relationships the principle of gratuitousness and the logic of gift as an expression of fraternity can and must find their place within normal economic activity" (CiV 36).

With these postulates, the Encyclical reiterates and augments a long-standing Catholic doctrine which "holds that authentically human social relationships of friendship, solidarity and reciprocity can also be conducted within economic activity, and not only outside it or 'after' it" (CiV 36). Conventional wisdom to the contrary, "Caritas in Veritate" argues: "The economic sphere is neither ethically neutral, nor inherently inhuman and opposed to society. It is part and parcel of human activity and precisely because it is human, it must be structured and governed in an ethical manner" (ibid.). In short, the Encyclical revives the Thomistic view that economic action must be seen from a humanistic perspective (CiV 41). In line with recent findings from behavioral economics, neuro-economics, institutional economics and empirical game-theory but also transcending their materialistic approaches, the Encyclical points to the human aspects and the humane prospects of business as an encounter of persons in service of the varied (and never only material) needs of one another. Because business is and means more than an exchange of wares and services, any reduction of human interaction in business to merely commercial transactions is being repudiated (Bradstock 2010).

According to "Caritas in Veritate," the binary logic of private egotism plus societal altruism fails not only practically in a globalized world, where the powers of the nation states to restrain business and to bend to the public interest are in constant decline; it is reproved on theoretical grounds as well.

In recent decades a broad intermediate area has emerged. . . . It is made up of traditional companies which nonetheless subscribe to social aid agreements in support of underdeveloped countries, charitable foundations associated with individual companies, groups of companies oriented towards social welfare, and the diversified world of the so-called "civil economy" and the "economy of communion." This is not merely a matter of a "third sector," but of a broad new composite reality embracing the private and public spheres, one which does not exclude profit, but instead considers it a means for achieving human 
and social ends. ... Without prejudice to the importance and the economic and social benefits of the more traditional forms of business, they steer the system towards a clearer and more complete assumption of duties on the part of economic subjects. And not only that. The very plurality of institutional forms of business gives rise to a market which is not only more civilized but also more competitive. ( $\mathrm{CiV} 46)$

This is both a very keen observation and an extremely clairvoyant prognostication of events. Indeed, in the last decades the Social Business sector has grown rapidly (Elkington and Hartigan 2008). The current blossoming of forms of integrated, or shared value creation can be attributed to the fact that their business models appear to harmonize much more with the integrative and comprehensive interests that people wish to realize in the economic arena (Porter and Kramer 2006). "Business activity has a human significance, prior to its professional one" (CiV 41) The human desire to contribute to the good, the wish to be useful, the need to find worthy approval, the appeal of social justice as well as the inspiration and energy drawn from shared visions and a common mission-in sum: the immanent dignity that lies in the service to the real needs of one's fellows (as opposed to the artificial creation of demand) - all these and further moral as well as spiritual, motives find their realization in those non-traditional businesses.

For these reasons, primarily, space "needs to be created within the market for economic activity carried out by subjects who freely choose to act according to principles other than those of pure profit, without sacrificing the production of economic value in the process" (CiV 37). This idea does not detract from the many secondary benefits that society can reap from the function of such social-value enterprises. "Alongside profit-oriented private enterprise and the various types of public enterprise, . . . commercial entities based on mutualist principles and pursuing social ends" can bring forth welcome "hybrid forms of commercial behavior" and foster an overall "attentiveness to ways of civilizing the economy" (CiV 38). By their very example such organizations can exert a beneficial influence on conventional business: making visible markets of unmet needs, highlighting alternative (more socially sustainable) business models, and underscoring overall the heuristic benefits of a human-centered hermeneutics of economic behavior. Yet their primary value lies in the fact that in subsidiary forms they are expressive of the essentially human quest for solidarity and aim to realize social justice in and through business (Cornuel, Habisch, and Kletz 2010).

\section{CONCLUSIONS}

According to Thomas Aquinas the human being, i.e., every human being, is naturally inclined towards moral conduct. If Thomas is right in his universal approach to human morality, indeed close attention to virtue as the inherent proclivity of human behavior has to be paid by any theory that aspires to be a truthful account of human affairs. The conceptualization of virtue cannot remain marginal to economics and business theory, since theories which describe human behavior only externally, without any attention to its internal prescriptive dimension, cannot but fail to understand and predict 
human agency properly. Ethical theories resting on such a truncated understanding of human nature tend to turn into self-fulfilling prophesies that privatize the idea of virtue into but one of the 'preferences' of the homo oeconomicus (Steele 2004). That is to say, neoclassical economics and its adherent ethical theories contribute nolens volens to the social construction of a world in their image. For absence of an adequate intellectual realization of the individual inclination to virtue, such theories unwittingly hamper its practical realization (Dierksmeier 2011).

We attempted to demonstrate how Thomas Aquinas's virtue ethics is of a truly inter-cultural relevance, whose beneficial implication become especially visible in the age of globalization. Thomas argues that there is an inter-personal dimension to virtue ethics (MacIntyre 1999) which allows for its application across cultural divides, and that this dimension stems from a concern for the common good, properly qualified as an endeavor to extend the practices of social justice to everyone. This endeavor cannot be relegated to the law alone (cf. Føllesdal and Pogge 2005) but must also find realization in the ambit of individual and Corporate Social Responsibility (Sison 2003). Virtue reaches farther and deeper than the law; it can operate where the latter lacks power and can extend beyond its commands. In today's world, where a global economy operates without being adequately regulated by a global government, the cultivation of virtue in the business sphere attains ever more significance in order to establish and safeguard a dignified life for each human person. As the current options of national and regional legislation are becoming increasingly restricted by an ever sharper international competition for global investment capital (Vogel 2005), and since ever more power is consequently shifting from political bodies to trans-nationally operating corporations (Stiglitz and Ocampo 2008), responsibility for the common good can no longer be delegated to political institutions alone. In stopping and reversing the various downward spirals of global competition, corporate 'coalitions of the willing' and private-public partnerships become increasingly important and, accordingly, ever more firms are beginning to take on wider social and environmental responsibilities (Bexell and Mörth 2010).

Yet not only factual reasons point us towards an understanding of the firm as an agent for good. We must on principle criticize the neoliberal bifurcation between a public and a private sector, between morals and markets, people and profits, etc. as resting on a mistaken anthropology (Ong 2006). The ever increasing contemporary voices, which proclaim that the ethical conduct of business can no longer be entrusted to the law alone (Solomon 1994), find in Thomas Aquinas an eminent predecessor. In his perspective, businesses are never actors outside the public realm (Melé 2005), but figure always as subsidiary agents of social justice (Aßländer 2011). Their social responsibilities are never mere additions to their strategic operations but, rightly understood, constitute their raison d'être. In our view, the emphasis on a forward-looking business ethics should therefore be based upon the individual and corporate capability as well as responsibility to do good. Virtue, in conclusion, is a very timely subject for business, not only because the current accountability and governance gaps in the global economy make its lack so patently felt (Kidder 2009) but rather because the idea of virtue makes the fundamental meaning and purpose 
of all economic activity transparent. In other words, the perspective of virtue allows us to zoom in on the 'moral capital' of business (Sison 2003).

Without denying the need for cultural diversification, Thomas's ethics meets the common need of humanity to establish an inter-culturally acceptable formulation of shared human concerns; an accomplishment that is, probably, even of greater significance today than in his time. Since Thomas's ethics intended to express the eternal structural laws of human reason and insofar as it achieved its timeless goal in its advocacy for aligning the idea of social justice with the essential preconditions of human flourishing, it will prove timely and relevant in the constantly changing contexts of our era (Dewan 2008). Since, to repeat, people are not only bound but also bonded by social justice, ethical management strategies can help reduce the transaction costs of business (Husted and Folger 2004). Thomas's instruction that justice justifies shows how through social justice as a relational virtue corporate conduct can be managed in a way that reconciles corporate and societal interests to the benefit of all concerned. A true commitment to justice helps firms to gain public acceptance through the moral adequacy and legitimacy of their business models (Koehn 1995). Efforts in Corporate Social Responsibility are therefore far more than mere prudent reputation management (Keys 2006). Rather, from a Thomistic vantage point, in responding to the ethical inclinations of stakeholders such endeavors appear as eminently reasonable investments in corporate health and longevity.

\section{REFERENCES}

Alves, A. A., and J. M. Moreira. 2010. The Salamanca School. London: Continuum.

Aquinas, T. 1929, 1937, 1947. Scriptum super libros Sententiarum (I and II, ed. P. Mandonnet, Paris, 1929); (III and IV, ed. M. Moos, Paris, 1937 and 1947). . 1941-1945. Summa theologiae. Ottawa: Studium dominicain. 1961-1967. Summa contra gentiles, ed. C. Pera, P. Marc, and P. Caramello. Turin: Marietti.

1970. Contra impugnantes Dei cultum et religionem, Sancti Thomae de Aquino Opera omnia. Rome: Editio Leonina, V. 41.

1972. Quaestiones disputatae de veritate, Sancti Thomae de Aquino Opera omnia. Rome: Editio Leonina, V. 22.

Argandoña, A. 1998. "The Stakeholder Theory and the Common Good," Journal of Business Ethics 17(9/10): 1093-1102.

Arjoon, S. 2000. "Virtue Theory as a Dynamic Theory of Business," Journal of Business Ethics 28(2): 159-78.

Aßländer, M. 2011. "Corporate Social Responsibility as Subsidiary Co-Responsibility: A Macroeconomic Perspective,” Journal of Business Ethics 99(1): 115-28.

Bailey, J. P. 2010. Rethinking Poverty: Income, Assets, and the Catholic Social Justice Tradition. Notre Dame, Ind.: University of Notre Dame Press.

Barbieri, W. A., Jr. 2001. "Beyond the Nations: The Expansion of the Common Good in Catholic Social Thought," The Review of Politics 63(4): 723-54. 
Bexell, M., and U. Mörth. 2010. Democracy and Public-Private Partnerships in Global Governance. New York: Palgrave Macmillan.

Bradstock, A., 2010. "Profits Without Honour? Economics, Theology and the Current Global Recession," International Journal of Public Theology 4(2): 135-57 (23).

Brown, O. J. 1981. Natural Rectitude and Divine Law in Aquinas. Toronto: Pontifical Institute of Medieval Studies.

Burnyeat, M. F. 1980. "Aristotle on Learning to be Good," in Aristotle's Ethics, ed. A. O. Rorty, 69-92. Berkeley: University of California Press.

Cahill, L. S. 1980. "Toward a Christian Theory of Human Rights,” The Journal of Religious Ethics 8(2): 277-301.

Carl, M. 1997. "Law, Virtue, and Happiness in Aquinas's Moral Theory," The Thomist 61(3): 425-47.

Celano, A. 1987. "The Concept of Worldly Beatitude in the Writings of Thomas Aquinas," Journal of the History of Philosophy 25: 215-26 (reprinted in Great Political Thinkers, ed. J. Dunn and I. Harris, vol. 7. Cheltenham: Edward Elgar Publishing Limited, 1994).

2007. "Phronesis, Prudence and Moral Goodness in the Thirteenth Century Commentaries on the Nicomachean Ethics," Mediaevalia Philosophica Polonorum 36: 5-27.

Cicero. 1994, De officiis, ed. M. Winterbottom. Oxford: Oxford University Press.

Cima, L. R., and T. L. Schubeck. 2001. "Self-Interest, Love, and Economic Justice: A Dialogue between Classical Economic Liberalism and Catholic Social Teaching," Journal of Business Ethics 30(3): 213-31.

Cornuel, E., A. Habisch, and P. Kletz. 2010. "The Practical Wisdom of the Catholic Social Teachings," Journal of Management Development 29(7/8): 747-54.

Cornwall, J. R., and M. J. Naughton. 2003. "Who Is the Good Entrepreneur? An Exploration within the Catholic Social Tradition," Journal of Business Ethics 44(1): 61-75.

Cortright, S. A., and N. Michael. 2002. Rethinking the Purpose of Business: Interdisciplinary Essays from the Catholic Social Tradition. Notre Dame, Ind.: University of Notre Dame Press.

Courcelles, D. d. 2005. "Managing the World: The Development of 'Jus Gentium' by the Theologians of Salamanca in the Sixteenth Century," Philosophy \& Rhetoric 38(1): $1-15$.

Crane, A., and D. Matten. 2007. Business Ethics: Managing Corporate Citizenship and Sustainability in the Age of Globalization. Oxford: Oxford University Press.

Crowe, M. 1977. The Changing Profile of the Natural Law. The Hague: Nijhoff Publishers.

Cullen, P., B. Hoose, and G. Mannion, eds. 2007. Catholic Social Justice: Theological and Practical Explorations. London: Continuum.

Dann, G. E., and N. Haddow. 2008. “Just Doing Business or Doing Just Business: Google, Microsoft, Yahoo! and the Business of Censoring China's Internet," Journal of Business Ethics 79(3): 219-34.

Dewan, L. 2008. Wisdom, Law, and Virtue: Essays in Thomistic Ethics. New York: Fordham University Press. 
Dierksmeier, C. 2011. “The Freedom-Responsibility Nexus in Management Philosophy and Business Ethics," Journal of Business Ethics 101(2): 263-83.

Dierksmeier, C., and M. Pirson. 2009. "Oikonomia versus Chrematistike: Aristotle on Wealth and Well-Being, Journal of Business Ethics 88(3): 417-30.

Elkington, J., and P. Hartigan. 2008. The Power of Unreasonable People: How Social Entrepreneurs Create Markets that Change the World. Boston: Harvard Business School Press.

Epstein, S. A. 2009. An Economic and Social History of Later Medieval Europe, 10001500. Cambridge: Cambridge University Press.

Finnis, J. 2005. “Aquinas's Moral, Political and Legal Philosophy,” in Stanford Encyclopedia of Philosophy, http://plato.stanford.edu/entries/aquinas-moral-political/.

Føllesdal, A., and T. W. M. Pogge. 2005. Real World Justice: Grounds, Principles, Human Rights, and Social Institutions. Dordrecht: Springer.

Frank, W. A. 2007. "Authority and the Common Good in Democratic Governance," The Review of Metaphysics 60(4): 813-32.

Franks, C. A. 2009. He Became Poor: The Poverty of Christ and Aquinas's Economic Teachings. Grand Rapids, Mich.: William B. Eerdmans Publishing Co.

González, A. M. 2003. "Ethics in Global Business and in a Plural Society," Journal of Business Ethics 44(1): 23-36.

Gratian. 1879-1891. Decretum, ed. E. Richter. Leipzig: Tauchnitz.

Greene, R. A. 1997. "Instinct of Nature: Natural Law, Synderesis, and the Moral Sense," Journal of the History of Ideas 58(2): 173-98.

Hall, P. M. 1992. “Towards a Narrative Understanding of Thomistic Natural Law," Medieval Philosophy and Theology 2: 53-73.

Henle, R. J. 1980. "A Catholic View of Human Rights: A Thomistic Reflection," in The Philosophy of Human Rights, ed. A. S. Rosenbaum, 87-94. Santa Barbara, Calif.: Greenwood Press.

Hoffmann, T. 2011. "Conscience and Synderesis," in The Oxford Handbook of Aquinas, ed. B. Davies and E. Stump, 255. Oxford: Oxford University Press.

Husted, B. W., and R. Folger. 2004. "Fairness and Transaction Costs: The Contribution of Organizational Justice Theory to an Integrative Model of Economic Organization," Organization Science 15: 719-29.

Iber, S. T. 2011. The Principle of Subsidiarity in Catholic Social Thought: Implications for Social Justice and Civil Society in Nigeria. New York: P. Lang.

Jacobsen, M., and O. Bruun. 2000. Human Rights and Asian Values: Contesting National Identities and Cultural Representations in Asia. London: RoutledgeCurzon.

Jordan, M. 1994, "The Pars moralis of the Summa theologiae as Scientia and as Ars," in Scientia und ars in Hoch- und Spätmittelalter, ed. I. Craemer-Ruegenberg and A. Speer, 468-81. Miscellanea Mediaevalia 22. Berlin: Walter de Gruyter.

Kelly, J. E. 2004. "Solidarity and Subsidiarity: Organizing Principles for Corporate Moral Leadership in the New Global Economy," Journal of Business Ethics 52(3): 283-95. 
Kenny, A. 1999. “Aquinas on Aristotelian Happiness," in Aquinas's Moral Theory: Essays in Honor of Norman Kretzmann, ed. S. MacDonald and E. Stump, 15-27. Ithaca, N.Y.: Cornell University Press.

Keys, M. M. 2001. “Aquinas's Two Pedagogies: A Reconsideration of the Relation between Law and Moral Virtue," American Journal of Political Science 45(3): 519-31.

2006. Aquinas, Aristotle, and the Promise of the Common Good. Cambridge: Cambridge University Press.

Kidder, R. M. 2009. The Ethics Recession: Reflections on the Moral Underpinnings of the Current Economic Crisis. Rockland, Maine: Institute for Global Ethics.

Knights, D., and M. O'Leary. 2006. "Leadership, Ethics and Responsibility to the Other," Journal of Business Ethics 67(2): 125-37.

Koehn, D. 1995. "A Role for Virtue Ethics in the Analysis of Business Practice," Business Ethics Quarterly 5(3): 533-39.

Kohls, J., and S. L. Christensen. 2002. "The Business Responsibility for Wealth Distribution in a Globalized Political-Economy: Merging Moral Economics and Catholic Social Teaching," Journal of Business Ethics 35(3): 223-34.

Koslowski, P. 2000. “The Limits of Shareholder Value,” Journal of Business Ethics 27(1/2): 137-48.

Küng, H. 1990. Projekt Weltethos. München: Piper.

Lottin, O. 1948. "Syndérèse et conscience aux XII et XIII ${ }^{\mathrm{e}}$ siècles," in Psychologie et morale aux XII et ${ }^{e} I I{ }^{e}$ siècles. Louvain: Abbaye du Mont César; Gembloux: J. Duculot. II(1): 103-349.

MacIntyre, A. C. 1999. Dependent Rational Animals: Why Human Beings Need the Virtues. Chicago: Open Court.

Maritain, J. 1947. The Person and the Common Good. New York: University of Notre Dame Press.

Melé, D. 1999. "Early Business Ethics in Spain: The Salamanca School (1526-1614)," Journal of Business Ethics 22(3): 175-89.

2005. "Exploring the Principle of Subsidiarity in Organisational Forms," Journal of Business Ethics 60(3): 293-305.

.2009a. Business Ethics in Action: Seeking Human Excellence in Organizations. New York: Palgrave Macmillan.

2009b. "Integrating Personalism into Virtue-Based Business Ethics: The Personalist and the Common Good Principles," Journal of Business Ethics 88: 227-44.

2010. "Practical Wisdom in Managerial Decision Making," Journal of Management Development 29(7/8): 637-45.

Nell-Breuning, O. von. 1983. Arbeit vor Kapital: Kommentar zur Enzyklika Laborem exercens von Johannes Paul II. Wien: Europaverlag.

Nell-Breuning, O. von, F. Hengsbach, and B. Emunds, 2002. Grundzüge der Börsenmoral. Münster: Lit.

Nixon, M. G. 2007. "Satisfaction for Whom? Freedom for What? Theology and the Economic Theory of the Consumer," Journal of Business Ethics 70(1): 39-60. 
Nussbaum, M. 1978. Aristotle's De Motu Animalium. Princeton, N.J.: Princeton University Press.

O’Brien, T. 2009. "Reconsidering the Common Good in a Business Context," Journal of Business Ethics 85: 25-37.

Ong, A. 2006. Neoliberalism as Exception: Mutations in Citizenship and Sovereignty. Durham, N.C.: Duke University Press.

Orel, A. 1930. Oeconomia Perennis, vols. 1 and 2. Mainz: Matthias.

Owens, J. 1991. "Value and Practical Knowledge in Aristotle," in Essays in Ancient Greek Philosophy IV: Aristotle's Ethics, 148-49. Albany: State University of New York Press.

Perkams, M. 2008. “Aquinas's Interpretation of the Aristotelian Virtue of Justice and His Doctrine of Natural Law," in Virtue Ethics in the Middle Ages: Commentaries on Aristotle's 'Nicomachean Ethics,' 1200-1500, ed. I. P. Bejczy, 131-52. The Hague: Nijhoff Publishers.

Peterson, J. 1997. "The Interdependence of Intellectual and Moral Virtue in Aquinas," The Thomist 61(3): 449-54.

Pinckaers, S. 1995. The Sources of Christian Ethics. Washington, D.C.: Catholic University of America Press.

Porter, M. E., and M. R. Kramer. 2006. "Strategy and Society: The Link between Competitive Advantage and Corporate Social Responsibility," Harvard Business Review 85(12): 78-92.

Reichberg, Gregory. 2002. "The Intellectual Virtues (Ia IIae, qq. 57-58)," in Essays on the Ethics of St. Thomas Aquinas: 131-47. Washington, D.C.: Georgetown University Press.

Rivas, L. G. 1999. "Business Ethics and the History of Economics in Spain, The School of Salamanca: A Bibliography," Journal of Business Ethics 22(3): 191-202.

Ross, J. F. 1974. "Justice Is Reasonableness: Aquinas on Human Law and Morality," The Monist 58(1): 86-103.

Ryan, J. 1942. "The Economic Philosophy of St. Thomas," in Essays in Thomism, ed. R. E. Brennan, 239-60. New York: Sheed and Ward.

Santos, J. C., and G. R. Laczniak. 2009. “'Just' Markets from the Perspective of Catholic Social Teaching," Journal of Business Ethics 89, Suppl. 1: 29-38.

Schumacher, L. 1949. The Philosophy of the Equitable Distribution of Wealth: A Study in Economic Philosophy. Washington, D.C.: Catholic University of America Press.

Sison, A. G. 2003. The Moral Capital of Leaders: Why Virtue Matters. Cheltenham: Edward Elgar Publishing Limited.

2008. Corporate Governance and Ethics: An Aristotelian Perspective. Cheltenham: Edward Elgar.

Solomon, C. R. 1994. The New Word of Business: Ethics and Free Enterprise in the Global 1990s. Lanham, Md.: Roman \& Littjefield.

Stammkötter, F.-B. 2001. "Die Entwicklung der Bestimmung der Prudentia in der Ethik des Albertus Magnus," in Albertus Magnus zum Gedenken nach 800 Jahren: Neue Zugänge, Aspekte und Perspektiven, ed. W. Senner. Berlin: Akademie Verlag. 
Steele, G. R. 2004. "Understanding Economic Man: Psychology, Rationality, and Values," American Journal of Economics and Sociology 63(5): 1021-55.

Stiglitz, J. E., and J. A. Ocampo. 2008. Capital Market Liberalization and Development. Oxford: Oxford University Press.

Striker, G. 1986. "Origins of the Concept of Natural Law," in Proceedings of the Boston Area Colloquium in Ancient Philosophy, vol. 2: 79-94.

Stump, E. S. 1997. “Aquinas on Justice," American Catholic Philosophical Quarterly, Supp. 71: 61-78.

Varacalli, J. A. 1992. "Whose Justice and Justice for What Purpose?: A Catholic NeoOrthodox Critique," International Journal of Politics, Culture, and Society 6(2): 309-21.

Velasquez, M., and F. N. Brady. 1997. "Natural Law and Business Ethics," Business Ethics Quarterly 7(2): 83-107.

Villa-Vicencio, C. 1999. "Christianity and Human Rights," Journal of Law and Religion 14(2): 579-600.

Vogel, D. J. 2005. "Is There a Market for Virtue? The Business Case for Corporate Social Responsibility," California Management Review 47(4): 20-45.

Westberg, D. 1994. Aristotle, Action, and Prudence in Aquinas. Oxford Theological Monographs, vol. 2: Oxford: Oxford University Press.

Williams, O. F. 1993. "Catholic Social Teaching: A Communitarian Democratic Capitalism for the New World Order," Journal of Business Ethics 12(12): 919-32.

. 2004. "The UN Global Compact: The Challenge and the Promise," Business Ethics Quarterly 14(4): 755-74.

Zagzebski, L. 2001. "The Uniqueness of Persons," The Journal of Religious Ethics 29(3): 401-23. 